\title{
En oplyst anerkendelsesrejse - et nyt perspektiv på stress
}

\author{
Af Pernille Steen Pedersen *)
}

\begin{abstract}
Resumé
Hvordan kan ledere og medarbejdere i fællesskab tage højde for stress i et moderne arbejdsliv? Dette spørgsmål er undersøgt i forskningsprojektet: "Ledelse, kerneopgave, arbejdsfællesskaber og stress", som er finansieret af parterne på det kommunale arbejdsmarked i regi af Fremfærd, CBS og 3 kommuner. Under navnet: "En oplyst anerkendelsesrejse" er der udviklet forskningsbaserede dialogværktøjer, der giver et nyt sprog og perspektiv på stress-håndtering i arbejdsfællesskabet. I denne artikel vil jeg fortælle om erfaringerne fra projektet samt præsentere de nye forebyggelsesværktøjer, der bl.a. skal hjælpe til at forstå forskellige reaktionsmønstre på højt arbejdspres og give input til dialoger herom. Forskningen bidrager til en praktisk ledelsesteori med særlig fokus på forebyggelse af stressrelateret sygefravær, som forøger ledere såvel som medarbejderes evne til at sætte sig i hinandens sted og skaber handlemuligheder.
\end{abstract}

Emneord: Ledelse, skam, stress, anerkendelse

\footnotetext{
*) Pernille Steen Pedersen er ph.d. og ansat som Post.doc på Institut for Ledelse, Politik og Filosofi på CBS. Hun har gennem en årrække beskæftiget sig med, hvordan ledelse kan tilrettelægges med henblik på at håndtere medarbejdernes stressrelaterede problemstillinger med særlig fokus på undersøgelse af skammens betydning som en ny og fremtrædende problematik i forhold til stress. ppe.mpp@cbs.dk, www.sundledelse.dk
} 


\section{A. Indledning}

\section{Baggrund}

"Det giver rigtig god mening at høre om moralske konflikter. Jeg ser på konflikter mellem medarbejdere på en helt anden måde. Tak for det, Pernille. Det er mega-brugbart som personaleleder."

"Jeg håber, at andre får nogle ahaoplevelser, omkring hvordan jeg oplever nogle ting. Jeg oplevede virkelig også at gå på arbejde og føle mig mere rummelig ift. nogle kollegaer, som reagerer lige præcis, som der bliver beskrevet.”

En leder og en medarbejder sætter her ord på deres møde med de nye forskningsbaserede værktøjer, som er omdrejningspunktet for denne artikel, og som er udviklet i forskningsprojektet: "Ledelse, kerneopgave, arbejdsfællesskaber og stress”. De tager afsæt i resultaterne fra min ph.d.-afhandling (Pedersen, 2016a), hvor jeg fandt en kobling mellem skam og stressrelateret sygefravær og beskrev denne skamfølelse ved hjælp af begrebet moralsk konflikt og reaktionsmønstrene problemløser og relationsmester. Disse fund er præsenteret i en tidligere artikel i nærværende tidsskrift (Pedersen, 2018). Nærværende artikel lægger sig således i forlængelse af min tidligere artikel, og det kan være en fordel at orientere sig heri for at få et bedre udbytte. I mit nye forskningsprojekt har jeg testet, om beskrivelserne af et skamproblem forekommer meningsfulde blandt kommunale ledere og medarbejdere, og om de kan omsættes til værktøjer, som giver ledere og medarbejdere følelsen af handlemuligheder ift. at håndtere og forebygge stressreaktioner i arbejdslivet.

At stress udgør et stort problem for både samfund, virksomheder og den enkelte er velkendt (se f.eks. Beskæftigelsesministeriets Ekspertrapport 2014; Arbejdsmiljøfondens strategi 2020), men stress-begrebet er omdiskuteret og bliver tilgået på mange forskellige måder (Se f.eks. Milsted, 2017). I den psykologiske litteratur er stressbegrebet primært baseret på definitioner, der fremhæver forholdet mellem personen og en omgivelse, der opfattes som en belastning, og som overstiger hans eller hendes ressourcer samt truer hans eller hendes velbefindende (Se f.eks. Netterstrøm, 2014). I min forskning er forholdet mellem krav og ressourcer også centralt, men jeg er gået mere i dybden og har undersøgt, hvad der karakteriserer de krav, som bliver særligt problematiske ift. sygemelding. Til denne opgave mobiliserer jeg begrebet "skam" til at give et sprog for et særligt problem, der ikke hidtil er beskrevet i den eksisterende stress-litteratur, nemlig at der kan være bestemte ledelsessituationer, hvor anerkendelse ikke virker. Objektivt kan personen se, at f.eks. en leder anerkender vedkommende, men skamfølelsen sætter personen ude af stand til at erfare det som anerkendelse (Pedersen, 2018). Der har i anerkendelseslitteraturen (Cooperrider \& Srivesta, 2017) været fokus på anerkendelsesafsendelsen, men ikke på anerkendelsesmodtagerens evne til at modtage anerkendelse og herunder de modstridende kræfter i den enkelte, som spiller 
ind i denne proces. Min forskning tager højde for, at den, der bliver anerkendt, skal evne at modtage anerkendelse, og derfor er overskriften på værktøjerne: "En oplyst anerkendelsesrejse".

\section{Oversigt}

Artiklen indledes med, at jeg kort behandler betydningen af ledelse ift. stressforebyggelse og fremhæver et relationelt perspektiv på ledelse med vægt på den skabelsesproces, ledelse vedrører. Dernæst introducerer jeg forskningsprojektet efterfulgt af en præsentation af de nye forebyggelsesværktøjer og forskellige erfaringer fra ledere og medarbejdere, der har afprøvet materialerne. I den afsluttende del af artiklen diskuterer jeg implikationerne for en ledelsespraksis med særlig fokus på forebyggelse af stressrelateret sygefravær.

\section{B. Ledelse og stress}

Der er bred enighed i litteraturen om, at ledelse spiller en central rolle i arbejdslivet, og at relationer mellem ledere og medarbejdere påvirker organisationers funktionsniveau (f.eks. Rost, 1991, 1995; Uhl-Bien, 1995). Hollander (1964) introducerede som én af de første begrebet "leadership" som en relationel proces med en gensidig udveksling og påvirkning mellem ledere og følgere, mens Rost (1995) retter opmærksomheden på, hvad ledere og dem, der bliver ledet, gør sammen.

Når det kommer til en kompleks problemstilling som forebyggelse af stressrelateret sygefravær, bliver ledelse og leder-medarbejder-relationer også afgørende. Således peger flere undersøgelser på, at ledelse og ikke mindst den direkte relation mellem ledere og medarbejdere spiller en afgørende rolle for medarbejderes psykiske sundhed og velbefindende (For et overblik, se Harms et.al., 2018), og der er evidens for, at ledelsesstøtte er vigtig for håndtering af arbejdsrelateret stress og udbrændthed (Halbesleben, 2006; Borg et.al., 2010). Derfor er der god grund til at se nærmere på konkrete måder at styrke relationerne mellem ledere og medarbejdere. Her er det afgørende at tage højde for kompleksiteten knyttet til stressforebyggende ledelsesindsatser.

\section{Forskningsprojektet}

Sigtet med forskningsprojektet har været at komme med ny viden omkring forebyggelse af stressrelateret sygefravær og at udvikle nye værktøjer til f.eks., at ledere og medarbejdere og kollegaer indbyrdes kan samarbejde om at hjælpe modtagelsen af anerkendelse på vej. Ny viden kan ikke komme uden at gennemgå et stadium, hvor kvalitative undersøgelser dominerer, idet den kvalitative forskning kan gå længere i undersøgelsen af de indbyggede antagelser og implikationer i teorierne, end man typisk kan ved brug af kvantitative metoder (Kvale \& Brinkmann, 2009). Forskningsprojektet tager således ikke afsæt i en ambition om at frembringe evidensbaseret viden, 
idet statistiske evidensstudier forudsætter 1) at vi ved, hvad det er vi måler, 2) at vi kan måle det rent praktisk. Afsættet for forskningen har været, at når det kommer til stress, så er det omdiskuteret, hvad stress overhovedet er, og derfor er der brug for en kvalitativ tilgang - især når ambitionen er at belyse problemstillinger, der vedrører følsomme mellemmenneskelige relationer, som folk ofte har svært ved at sætte ord på.

Derfor blev der i projektet primært anvendt kvalitative interviews til empiriindsamling - dog suppleret med spørgeskemaer til begrebsudvikling samt evaluering af materialerne. Jeg transskriberede alle interviews og analyserede dem med afsæt i en problematiseringsanalytisk metode (For uddybning af den anvendte metode, se Pedersen, 2018 og Pedersen \& Krarup, 2018).

Empiriindsamlingen foregik i 2 runder. Med henblik på at få et grundlag til at udvikle materialer ud fra gennemførtes i første runde i alt 56 kvalitative interviews med ledere og med medarbejdere fra de tre deltagende kommuner, Rudersdal, København og Skanderborg. I anden runde blev materialerne afprøvet blandt ledere og medarbejdere fra hhv. 4 børnehuse i Skanderborg Kommune, et plejecenter og hjemmeplejen i Rudersdal Kommune. Afprøvningen foregik i et forløb på 8 uger, hvor lederne og udvalgte medarbejdere fik til opgave at føre logbog over deres erfaringer. Kvalitative interviews med ledere og medarbejdere dannede sammen med evalueringsskemaer og logbogsnotaterne afsæt for, at jeg kunne vurdere potentialet samt indholdet i materialerne og få input til at videreudvikle og tilpasse materialerne, så de kunne imødekomme lederes og medarbejderes konkrete behov. F.eks. stod det klart for mig, at der var behov for at udvikle nogle mere enkle værktøjer som supplement til de mere teksttunge værktøjer. Derfor udviklede jeg dialogkort, som blev afprøvet på en bredere gruppe af offentlige arbejdspladser, f.eks. 3 skoler, 2 gymnasier, arbejdspladser inden for vej og park, HR-afdelinger samt uddannelsesinstitutioner.

\section{En oplyst anerkendelsesrejse}

\section{Afsættet}

Jeg vil nu præsentere de 3 anerkendelsesværktøjer, som udgør det, jeg kalder "en oplyst anerkendelsesrejse”. Et gennemgående omdrejningspunkt for værktøjerne er at bibringe ledere og medarbejdere en øget forståelse for forskellige reaktioner på pressede situationer og komme med input til konkret inspiration til, hvordan den nye viden kan omsættes til at styrke arbejdsfællesskaber. En medarbejder skriver i sin logbog:

”At læse om problemløser og relationsmester har gjort mig klog på, hvor jeg selv befinder mig $\mathrm{i}$ en given situation og har samtidig givet mig en indsigt i en anden måde at reagere og handle på. Netop den indsigt giver mig en bedre forståelse af, hvorfor mine kollegaer 
reagerer, som de gør. Det hjælper mig til at få en anden tilgang, som jeg oplever forbedrer vores samarbejde."

For alle tre værktøjer gælder, at afsættet har været, at der er brug for en opmærksomhed på relationer og ikke kun forskning, der lægger vægt på risikofaktorer. Til denne ambition hører et ønske om at belyse stresshåndtering i arbejdslivet ud fra et ikke-patologisk blik, hvor fokus rettes mod at skabe betingelser for et velfungerende arbejdsmiljø, der anerkender, at alle slags følelser, herunder angst for at begå fejl og tvivl, er en del af det at være menneske. Dette peger på, at profylaktiske indsatser og ledelsesmuligheder ift. at håndtere oplevelser af et stort arbejdspres og moralske konflikter i et arbejdsfællesskab kommer i forgrunden, til forskel fra et individfokus, hvor det handler om, at den enkelte får redskaber til at blive mindre stresset. Her bliver måden, vi er sammen på og samarbejder omkring arbejdsopgaver centralt, hvilket denne leder sætter ord på her:

"Dialogerne, vi havde med hinanden var helt anderledes end meget andet, vi har prøvet. Det her kan noget særligt, fordi vinklen er en anden. Det italesætter nogle andre ting og handler ikke om: "Er du stresset" og "hvem skal tage opgaver fra dig", men i stedet: "Hvad er egentlig en hjælp for dig. Og hvordan kan du hjælpe dig selv også?”

\section{Anerkendelsesvarktøj 1: Det foelles sprog}

Anerkendelsesværktøj 1: "Det fælles sprog" indeholder en nærmere beskrivelse af hvilke situationer, der potentielt kan indebære stressreaktioner (moralske konflikter), hvad der kendetegner det problematiske aspekt ved sådanne konflikter (skam) og ikke mindst variationerne i hvilke typer situationer, der kan fremkalde moralske konflikter, og hvordan de håndteres (to reaktionsmønstre). Ambitionen med anerkendelsesværktøj 1 har været at give arbejdspladser et fundament af fælles viden i form af et sprog til at tale om de mere skjulte og følelsesmæssige sider ved det at opleve et stort pres i arbejdslivet. Cases, citater og situationer fra dagligdagen både set fra en leders og en medarbejders synsvinkel skal hjælpe til at både ledere og medarbejdere får et nuanceret blik på nogle af de bekymringer og forestillinger, der kan præge en stressramt tænkning.

\section{Anerkendelsesvoerktøj 2: Øvelser}

Anerkendelsesværktøj 2 leverer input og praktiske øvelser til at hjælpe ledere og medarbejdere med at bringe den nye viden i spil i forskellige situationer i hverdagen, f.eks. i forbindelse med forberedelse og afholdelse af MUS-samtaler. En leder skriver herom i sin logbog:

"Jeg havde MUS i går, og der havde jeg brug for noget omkring anerkendelse. Jeg gik ind og tog nogle af øvelserne. Det gav mig viden og inspiration til at spørge på den mest konstruktive måde. Medarbejderen syntes, at det var rigtig godt.” 


\section{Anerkendelsesvoerktøj 3: Dialogkort}

Anerkendelsesværktøj 3 består af en række dialogkort til at tale om emner, det ellers kan være svært at tage op. Kortene er udviklet på baggrund af de teoretiske begreber, problemløser og relationsmester og tager afsæt i interviews med ledere og medarbejdere. Der er 4 sæt dialogkort inden for temaerne: Anerkendelse, Kollegaskab, Ledelse og Moralske konflikter. Et introduktionshæfte med eksempler på, hvordan kortene bringes i spil i forbindelse med f.eks. personalemøder og skal sikre, at arbejdspladser uden hjælp udefra kan arbejde med kortene.

Til hvert tema er der 3 runder med spørgsmål.

Den første runde indeholder hverdagssituationer, som er potentielt stressfremkaldende, efterfulgt af svarmuligheder i form af udsagn fra ledere eller medarbejdere. Her et eksempel fra ledelseskortene:

Du bruger mere tid på opgaverne, end rammerne tillader. Hvilke af disse to udsagn passer bedst på, hvordan din leder kan hjælpe dig?

- $\quad$ Min leder skal først og fremmest lytte og spørge mere ind til det, jeg fortæller

- $\quad$ Min leder skal først og fremmest hjælpe med at komme med en løsning

Den anden runde består af tre kort med citater. Deltagerne vurderer, hvor genkendeligt de finder citatet og uddyber efterfølgende svar. Til denne runde er der en spilleplade med fem felter gående fra "Kan helt genkende mig selv i citatet" til "kan slet ikke genkende mig selv i citatet". Et citat kunne lyde:

"Det er dejligt, når min leder er opsøgende og kommer af sig selv, så jeg ikke behøver at ringe efter min leder."

Den tredje runde indeholder åbne spørgsmål, der lægger op til, at man kan komme i dybden med forskellige emner med relevans for stress-håndtering i hverdagen, f.eks.:

"Hvad forbinder du med anerkendelse, og hvad forbinder du ikke med anerkendelse? Fortæl om en situation, hvor du har følt dig anerkendt.”

\section{Erfaringer}

Evalueringen af værktøjerne fokuserede på to forhold. Jeg var interesseret i at finde ud af, om ledere og medarbejdere finder beskrivelserne af skam, moralske konflikter og to reaktionsmønstre relevante og genkendelige, og jeg var interesseret i at finde ud af, om værktøjerne giver 
medarbejdere og ledere oplevelse af handlemuligheder. Evalueringsskemaer, kvalitative interviews og logbogsnotater dannede grundlaget for evalueringen.

\section{a. Relevante beskrivelser - genkendelse}

"Jeg kan ikke forestille mig et andet ord, der er bedre dækkende end skam. For mig er skam det fineste ord, altså den rummer så meget flovhed og mindreværd over faktisk godt at kunne se det rationelle i mange ting, men ikke at kunne udleve det eller handle derefter."

Sådan skriver en medarbejder og påpeger, ligesom mange andre har gjort, at begrebet skam giver mening. Især dem, der selv har haft stress inde på livet, finder, at skam-begrebet giver en præcis måde at beskrive oplevelser og erfaringer ifm. stress, ligesom begrebet om moralske konflikter vækker almen genkendelse. I forskningsprojektet har jeg kvalificeret beskrivelserne af den moralske konflikt som en almen konflikt, karakteriseret ved oplevelser af ikke at kunne leve op til egne forventninger, med særlig henvisning til en faglig stolthed og ledsagende usikkerhed ift. eget værd. Jeg undersøgte, hvilke aspekter ved denne oplevelse, som kan forklare forskellen mellem dem, der kan blive på arbejdspladsen, og dem, der ender med at blive sygemeldt. Udslagsgivende blev forekomsten af en tiltagende mistillid til sig selv og til andre kombineret med en oplevelse af afmagt eller hjælpeløshed over for situationen. Med den voksende mistillid fulgte nemlig det, jeg allerede havde set i mit første forskningsprojekt, nemlig at den pågældende i tiltagende grad blev svær at påvirke (Pedersen, 2018; Pedersen \& Gudmann-Højer, 2017). En medarbejder hæfter sig ved oplevelsen af magtesløshed:

"I en af historierne kan medarbejderen ikke sætte ord på længere - og for f... Det er sådan. Lige præcis sådan, når det hele ramler. Man kan ikke handle (andet end på autopilot med kendte opgaver) og kan ikke bede om hjælp, fordi det hele vælter sammen og refleksion og tanke forsvinder i centrifugeringen".

Det er et gennemgående mønster i tilbagemeldingerne, at det er en stor hjælp at læse om andres erfaringer og derigennem erfare, at de følelser, man troede man var alene med, er følelser, andre også har haft. "Jeg får fornemmelsen af, at jeg ikke er alene med de konflikter, der foregår- både udenfor men også inden i mig”, udtrykker én af dem jeg har interviewet, mens en anden formulerer skriver i sin logbog:

"Når du skriver moralske konflikter, får jeg en klump i halsen. Jeg føler mig ramt. Men det er rart, at der bliver sat ord på de tanker og følelser, der handler om de utilstrækkelighedsfølelser som jeg bilder mig selv ind, at jeg står alene med. Nu kan jeg godt se, at jeg ikke står alene, hvis jeg selv tør sige det højt. Tør være sårbar.” 


\section{b. Brugbare voerktøjer - handlemuligheder}

"Nogle gange, når jeg forstår, hvorfor jeg gør ting, så kan jeg godt holde op, Det er ikke det samme som at være bevidst om det. Jeg skal forstå grunden. ”

En medarbejder reflekterer her over, hvad der skal til, for at han kan ændre adfærd og formulerer en central pointe, nemlig at handlinger og ændringer af en uhensigtsmæssig adfærd både kræver en bevidstgørelse og en forståelse. Derfor er det ofte utilstrækkeligt, når vi som forskere fokuserer på at komme med moraliserende opfordringer til, hvad et menneske bør gøre, f.eks. "sige fra" eller "sige pyt". Det gælder især for stressramte, hvor opfordringer til at sige fra eller tage sig sammen kan virke som en hån, fordi det slet ikke opleves som en mulighed. De materialer, jeg har udviklet, erstatter sådanne råd med forklaringer på, hvorfor det kan være svært at sige fra og sige pyt. Tilbagemeldingerne viser, at materialerne netop bidrager til en øget forståelse. F.eks. fremhæver en medarbejder, at materialerne hjælper til at "... at reflektere over situationer, man måske ikke før har gjort", men en anden understreger gevinsten ved "... at få sat ord på, hvordan man kan reagere, når usikkerheden opstår".

Det har været afgørende for mig at udvikle fælles værktøjer, der hjælper os til at sætte os i den andens sted. Derfor præsenterer jeg erfaringer set fra den stressramtes, kollegaers og lederes perspektiv. En medarbejder fremhæver netop, hvordan hun har fået en større forståelse for lederens situation, fordi materialerne gav anledning til tanker om "... hvad er det faktisk, min leder skal have hånden på".

Især beskrivelserne af de to reaktionsmønstre har givet anledning til nye perspektiver på egne og andres behov, hvilket er afgørende for, at f.eks. ledere kan give en relevant feedback til medarbejdere. En leder fortæller, at beskrivelserne har givet "en mere proecis måde at imødekomme ledelsesbehovet hos den enkelte". For kollegaskabet har beskrivelsen af de to reaktionsmønstre også vist sig at have en effekt, hvilket kan ses i denne udtalelse fra en medarbejder:

"Indsigten i og påmindelsen om "at vi alle sammen er mennesker", og at vi reagerer forskelligt - både i pressede og ikke pressede situationer- flytter mit fokus fra navlepillende til mere forstående og rummelig over for andres reaktioner på mine reaktionsmønstre, så jeg ikke føler mig "alene”, når hverdagen ramler."

For nogle var der dog for meget teksttungt materiale, og derfor udviklede jeg dialogkort, som nævnt ovenfor. Blandt de 200 ledere og medarbejdere, der har afprøvet kortene, svarer 98 procent, at de i kortene finder inspiration til dialoger om, hvordan man kan støtte hinanden på en arbejdsplads og få viden om, hvordan man selv og andre reagerer i forskellige arbejdssituationer. De medarbejdere, 
der ikke fandt kortene anvendelige fremhævede, at de var bekymrede for, at der ikke blev fulgt op på dialogerne, og at ledelse fik en nem undskyldning for at kunne "satte hak af ved at have gjort noget for trivslen". Sådanne bekymringer er relevante og viser, at det er vigtigt, at kortene integreres i et løbende fokus på at understøtte et godt arbejdsmiljø.

Langt de fleste tilbagemeldinger var dog positive. Bl.a. uddyber en medarbejder i sin evaluering, at kortene hos dem var en "dialogigangsatter inden for nogle temaer, som normalt kan vare svare at tale om", mens en anden fremhæver kortenes evne til at italesætte relevante erfaringer:

"Det er en kæmpe hjælp til at få sat ord på nogle ting, som det kan være svært at finde ord for. Når jeg læser kortene, så kan jeg godt sige; jamen det er jo det, jeg mener, eller det er sådan jeg har det. Så udsagnene er super, super gode."

Tilbagemeldingerne på dialogkortene har været positive, og det er fremhævet, at de både giver anledning til, at den enkelte kan reflektere over sit eget behov for ledelse, kollegastøtte og håndtering af høje krav, samtidig med at de skaber en indsigt i andres behov og måder at håndtere krav. For mange var det en øjenåbner at se, hvor forskellige vi er som mennesker. Det blev fremhævet af flere, at kortene gjorde det lettere at tale om potentielt konfliktfyldte emner, netop fordi fokus flyttes fra at være meget personlige til at tale mere neutralt ud fra citater. En medarbejder beskriver denne erfaring sådan her:

"Vi fandt ud af, hvor forskellige vi er. Vi havde nogle gode snakke, som blev bundet op på kortene, og havde kortene ikke været der, så ville dialogerne have været meget mere problematiske. Sådan mere konfliktfyldte. Kortene bidrager til, at konfliktfyldte ting bliver nemmere at snakke om."

\section{E. Diskussion}

Vi håber ofte på den lette løsning, den ene enkle ændring, der vil løse vores problemer i en fart. Men få ting i livet fungerer på denne måde. Det kræver øvelse, vedvarende træning og refleksion undervejs at opbygge den fælles praksis, det er at etablere en anerkendende kultur. Der er ingen tvivl om, at lederen og den overordnede ledelse på en arbejdsplads spiller en afgørende rolle i at gå forrest og prioritere tid til og opmærksomhed på at bruge værktøjerne, men det er vigtigt for mig at understrege, at den oplyste anerkendelsesrejse er et fælles anliggende. Der er etablering af en platform mellem praksis, policy og Universitet, der vil arbejde med partnerskaber på flere planer og den sommerfuglemodel, som Charlotte Biil anbefaler i sin artikel, meget relevant. For der er ikke noget quick fix, når det drejer sig om at få et nyt paradigme med en ny anerkendelsespraksis i spil 
på de danske virksomheder. Dette erstatter naturligvis heller ikke den ligeledes vigtige kamp for rimelige arbejdsvilkår og det dertilhørende strukturelle fokus. Jeg ser dog udvikling af forskningsbaserede værktøjer til at forbedre mellemmenneskelige relationer på arbejdspladserne som et kerneområde for en fremtidig forskning. For ved siden af de ofte belyste samfundsmæssige og strukturelle aspekter ved stressproblemer, findes der et andet niveau, som er relevant, og som vedrører individer i relationer. Den individualisering, jeg vil undgå, er, at løsningen bliver individet. Jeg er bekymret for de mange mellemledere, der pålægges at skulle stressforebygge - men som står uden realistiske værktøjer, der tager højde for, hvordan man som leder (og ikke som terapeut) kan håndtere medarbejderes og egne (forskellige) følelsesmæssige reaktioner på de strukturelle betingelser, der kendetegner det moderne arbejdsliv. Derfor er mit fokus eksplicit at komme med input til at gøre praksis bedre ud fra den virkelighed, jeg ser, når jeg er ude på arbejdspladser, snarere end på at kritisere de nuværende forhold, finde årsager til sygemelding eller komme med løftede pegefingre ift., hvordan man som menneske bør være, og hvad man som menneske bør lade være med.

Jeg vil gerne understrege det foreløbige i mit arbejde. Det er ikke en fyldestgørende beskrivelse af de mange og forskelligartede problemstillinger, der er relateret til forebyggende håndtering af stressreaktioner i arbejdslivet. Det dækker en særligt forskningsinteresse, der angår spørgsmålet om, hvordan et af psykologiens største enkeltbegreber: Skam gør sig gældende i det moderne arbejdsliv, samt hvordan fælles viden om dette og konkrete input til dialoger om forskellige typer støtte kan bidrage til en anerkendelseskultur på arbejdspladsen. Der er, som med al anden ny forskning, behov for at videreudvikle både det teoretiske grundlag og de praktiske værktøjer. De målinger, der er foretaget af den umiddelbare tilfredshed og udbytte af materialerne, er således alene en indikator for et potentiale. Hvorvidt værktøjerne rent faktisk kan bidrage til at forebygge stressrelateret sygefravær vil kræve både mere viden og et helt andet studie, hvor indsatser kan testes kvantitativt (kontrolgrupper etc.).

\section{F. Konklusion}

"Der er meget anerkendelse i at blive ramt, og med dit begreb om skam har du virkelig ramt på sømmet, hvordan jeg har haft det, dengang jeg blev sygemeldt med stress."

Jeg forsøger at tilbyde et perspektiv på stressforebyggelse, som vægter opkvalificering af relationerne på arbejdspladsen som et centralt element, og som tager højde for, at mennesker har brug for forskellig slags ledelsesstøtte, ikke mindst når de oplever modgang. Der findes ingen "onesize-fits-all" rådgivning, og det er ikke nok at udstyre ledere med en slags "grønspættebog" i ledelse, fordi ledere er ligeså forskellige som medarbejdere, og derfor leder forskelligt. Derfor har jeg 
udviklet materialer og dialogkort for at give ledere og medarbejdere lejlighed til at forberede sig på at kunne tage problemerne i opløbet.

Jeg ser et stort potentiale $\mathrm{i}$, at en fremtidig ledelsestræning netop kan inkorporere dette forskningsprojekts afdækning af forskelige former for ledelsesstøtte, der tager højde for medarbejderens anerkendelsesbehov i situationer med moralske konflikter (Pedersen, 2016b, 2018). Det er til denne opgave, at begreberne problemsløser og relationsmester er udviklet, og som jeg håber på at kunne videreudvikle i samarbejde med praksis. - en forskningsopgave, jeg har viet resten af mit forskerliv til. Lad mig afrunde med en udtalelse fra en leder, som indfanger min ambition.

"At tale om skam og moralske konflikter er jo ikke noget, vi har italesat i vores arbejdsmiljø før, og de første havde det også meget underligt med de her ord. Men når vi dykker ned i det og begynder at få de to reaktionsmønstre på, så oplever jeg altså, at medarbejdere kan komme på banen på en helt anden måde, end de har været før. Materialet gav et andet sprog at tale om, hvordan vi kan hjælpe hinanden, og hvordan vi kan være hinandens arbejdsmiljø." 


\section{Sådan kan du bringe dialogkortene i spil på din arbejdsplads:}

Forberedelse: Skriv ud til personalegruppen, at du gerne vil sætte fokus på trivsel på næste personalemøde, og at du har fundet et nyt, spændende materiale. Alliér dig evt. med TR og Arbejdsmiljørepræsentanten. I kan evt. spille nogle af kortene på forhånd, så I kender dem.

Før spillet: På mødet introducerer du kortene. Læs evt. reglerne op (de fremgår af anerkendelsesværktøj 3) og mind deltagerne om, at der ikke er nogle rigtige og forkerte svar. Herefter kan du evt. spille den video, der er udviklet, og som også ligger på hjemmesiden.

Afrunding: Når der er 10 minutter tilbage, afbryder du dialogerne og siger, at alle skal spille opsamlingskortet (husk at informere om dette, inden I går i gang). Er der tid, kan I lave en opsamling i plenum.

\section{Om forskningsprojektet:}

Forskningsprojektet: "Ledelse, kerneopgave, arbejdsfællesskaber og stress" er samfinansieret af CBS, Fremfærd og Rudersdal Kommune, Skanderborg Kommune og Københavns Kommune.

Fremfærd er et samarbejde mellem parterne på det kommunale arbejdsmarked om at udvikle velfærdssamfundets kerneopgaver. Projektet har udviklet og afprøvet værktøjer, som giver ledere og medarbejdere mulighed for at arbejde med anerkendelse på nye måder som led i forebyggelse af stressrelateret sygefravær.

Værktøjerne kan gratis downloades på: https://vpt.dk/nytperspektivpaastress.dk 


\section{Referenceer}

Arbejdsmiljøfondens strategi 2020. Arbejdsmiljøfonden.

Beskæftigelsesministeriets Ekspertudvalgs Rapport (2014). Beskæftigelsesministeriet.

Borg V., Nexø, M.A, Kolt, I. V. \& Andersen, M. F. (2010). Hvidbog om mentalt helbred, sygefravær og tilbagevenden til arbejde. Det Nationale Forskningscenter for Arbejdsmiljø.

Cooperrider, D. \& Srivastva, S. (2017). Research in organizational change and development, Emerald Publishing Limited.

Harms, P.D., Credé, M., Tynan, M., Leon, M., Jeung, W. (2017). Leadership and stress: A meta-analytical review. I: The Leadership Quarterly 28, s. 178-184. https://doi.org/10.1016/j.leaqua.2016.10.006

Hollander, E.P. (1964). Leaders, Groups and Influence. New Your: Oxford University Press

Kvale, S., \& Brinkmann, S. (2009). Interview - Introduktion til et håndværk. København: Hans Reitzel.

Milsted, T. (2017). Tema om stress: Uenighed om definitionen hæmmer debatten i: Featured/Liv \& Mennesker

Netterstrøm, B. (2014). Stress og arbejde - nyeste viden om årsager, konsekvenser, forebyggelse og behandling. Hans Reitzels forlag.

Pedersen, P.S. (2016a). Udkast til et nyt coping-begreb - en kvalifikation af ledelsesmuligheder for at forebygge sygefravoer ved psykiske problemer. CBS. Ph.d.-serie 05/2016.

Pedersen, P.S. (2016b). Slip stress ud af skammekrogen - et forsvar for arbejdsfoellesskabet. Kristelig Dagblads Forlag.

Pedersen, P.S. \& Gudmand-Høyer, M. (2017). Modsatrettede forpligtelser: Skam og stress i arbejdslivet. I: Tidskrift for Erhvervspsykologi, vol. 15.

Pernille, P.S. \& Krarup, T. (2018). Foucault og problematiseringsanalyse, en analysemodel. I: Kvalitative analysemetoder i sundhedsforskning, Gilberg, Frederik Alkier og Hounsgaard, Lise. Forlaget Klim.

Pedersen, P.S. (2019). Skam æder anerkendelser op - præsentation af et skjult ledelsesproblem. I: Samfundslederskab i Skandinavien 34(1). https://doi.org/10.22439/sis.v34i1.5668

Rost, J.C (1991). Leadership for the twenty-first century. London:Praeger.

Rost, J.C (1995). Leadership: a discussion about ethics. I: Business Ethics Quarterly 5(1), s. 129-142. https://doi.org/10.2307/3857276 
Uhl-Bien, M. (2005). Implicit theories of relationships in the workplace. I: B. Schyns \& J.R. Meindl (Red.), The future of leadership development, s. 129-147. New Jersey: Lawrence Erlbaum Associates Inc., Publishers.al

Uhl-Bien, M. (2006). Relational Leadership Theory: Exploring the social processes of leadership and organizing. I: The Leadership Quarterly 17, s. 654-676.

https://doi.org/10.1016/j.leaqua.2006.10.007 